\title{
Verbal morphosyntax in Southwest Mande: elements of reconstruction
}

\begin{abstract}
The article is written after the recent conference report on some of the preliminary results of the collective research project "Towards Proto-Niger-Congo: Comparison and Reconstruction". It presents some comparative data on Southwest Mande verb morphosyntax and thoughts on the possibility of reconstructing the system of verbal markers in the protolanguage.
\end{abstract}

Keywords: Mande languages, reconstruction, verbal system, morphology, syntax, African languages.

In September 2012, the author of this paper was glad to take part in The International Congress "Towards Proto-Niger-Congo: Comparison and Reconstruction", organized in Paris by a group of scholars who are still keen on reconstructing distant proto-languages despite the fact that the world of mainstream linguistics seems to be gradually losing interest in language kinship and shifting its focus to other sub-disciplines. The participants presented some of their recent achievements in the comparative analysis of language groups and families belonging to the largest genetic grouping ever proposed: the Niger-Congo macrofamily, consisting of some 1500 tongues spread all over Sub-Saharan Africa, from the Senegal to the Orange River. They also agreed to prolong their cooperation so as to undertake a thorough and contemporary reconstruction of what could be reasonably defined as Proto-Niger-Congo, a language that was proposed by Joseph Greenberg some fifty years ago, yet has never been substantially approved through strict comparative analysis.

One of the teams that took shape during the Congress became specifically targeted on the reconstruction of Proto-Mande, the ancestral language of a relatively large West African family whose members have been relatively well studied. The team, led by the prominent Mandeist Prof. Valentin Vydrin, are to present a valid outlook of the family protolanguage, based on the analysis of phonology, morphosyntax and lexicon of the modern Mande languages. The current paper should be seen as a small step towards achieving this goal.

The Southwestern group of Mande languages (SW Mande from here on), consisting of six units, is spread across three republics of West Africa. Kpelle and Looma are both spoken in Liberia and Guinea, Bandi is found only in Liberia, and Zialo is across the border in Guinea, while Mende and Loko are closely related languages of Sierra Leone. Descriptions of the majority of these languages have existed already since the early $20^{\text {th }}$ century, and their internal classification, according to which Kpelle is considered to have been the first offshoot from the proto-language, is, to the best of my knowledge, accepted by all the relevant scholars. Within Mande, the closest relatives for SW Mande languages are Vai-Kono, Soso-Jalonke and other languages that belong to the Western branch of the family.

Comparative research on SW Mande languages is represented by just a few papers, which include Dwyer 1973 with a complex tonology analysis, Выдрин 2006 that deals mostly with 
Table 1.

\begin{tabular}{|c|c|c|c|c|c|c|}
\hline Series & 1sg. & 2 sg. & $3 s g$. & 1pl. & $2 \mathrm{pl}$. & $3 p l$. \\
\hline Basic & *né & $*_{i}^{\prime} / * e^{\prime}$ & $*_{i} / * \mathrm{e}$ & *mù & *Wó & *tì \\
\hline Imperfective & *ńàá & *yáà & *ǹ̀à & *màà & *wáà & *tàà \\
\hline Focalised & *ná & *íyá / *bíyá & *à & *mùyà & *wóyá & *tìyà \\
\hline Comitative / Instr. & *ń-yé & *íyé & *lá & *mùyè & *wóyè & *tìyè \\
\hline Object & *ń- & *í- & *ỳ- & *mù- & *wó- & *tì- \\
\hline Possessive & *ńí- / *ńé- & $*_{1-}^{\prime}$ & *'̀̀- & *mù- & *Wó- & *tì- \\
\hline Imperative & - & ${ }^{*} \varnothing$ & - & $\begin{array}{l}\text { *mù (du.), } \\
\text { *kàmù (pl.) }\end{array}$ & *kà & - \\
\hline Negative & * & *yéc̀ & * ̀̀̀̀ & *mù̀̀é & *Wóćc̀ & *tì̀̇é \\
\hline
\end{tabular}

Table 2.

\begin{tabular}{|c|c|c|}
\hline Original semantics & Meanings & Examples \\
\hline Motion & $\begin{array}{l}\text { prospective, future, } \\
\text { inchoative, conditional }\end{array}$ & $\begin{array}{l}\text { Loko ba 'come', Vai na 'come', Gban nù 'come', Kagoro na } \\
\text { 'come', Mano ló 'go', Wan zò 'come' }\end{array}$ \\
\hline Phase & perfective, resultative & Jalonke banta 'finish', Kagoro máy 'close' \\
\hline Existence & durative, habitual & Seenku sín 'be', Dyula bé 'be', Busa $g \supseteq$ 'stay' \\
\hline Perception & prospective & Looma ká 'see’ \\
\hline Volition & prospective, future & Zialo po 'want' \\
\hline
\end{tabular}

phonology and nominal morphosyntax, and, most recently, papers by K. Babaev $(2010,2011)$ that compare person marking systems in SW Mande.

The SW Mande tongues are known for their mostly isolating grammar structure and quite scant morphology. Naturally, these features are combined with super-short morphs (mostly of the CV or CVN types) and a vast and complicated tonology. Most languages of the group share a system of two level underlying tones, but they tend to mutate and interchange according to a variety of complicated rules within a syntactic group, so the surface tone picture may almost never reflect the original lexical tones.

The morphosyntax of SW Mande is therefore hard to analyse even on the synchronic level, but diachronic analysis reveals even more serious obstacles. Since morphemes are short, verbal grammatical markers and auxiliaries often become impossible to compare. Some of the verbal markers and clitics have a V / N structure which cannot be found among other parts of speech; this makes it impossible to compare diachronic changes in grammatical morphemes with the ones that take place in verbal or nominal roots. Moreover, it seems that the markers are quite unstable in the particular languages and tend to be replaced by newer morphemes very quickly. At least some of them in certain languages of the group look brand new, and their genesis is easy to trace. But the older markers that they replace can sometimes be found only in the status of "rudiments". There are cases of fusion of several (up to three) verbal markers into one, as well as alternating usage of several (older and newer) markers in the same meaning.

SW Mande languages are characterised by a number of morph boundary samdhi processes that look similar to the initial consonant mutations in Celtic languages of Europe. These happen to be caused by initial or final ${ }^{*} \mathrm{~N}$, the homorganic nasal which was dropped almost everywhere (except for Kpelle, where it was preserved in word-final position). The drop of ${ }^{*} \mathrm{~N}$ 
has resulted in a number of consonant alternations not only word-initially, but also on the boundaries of morphs within a word.

For these and other reasons, it is sometimes advisable to reconstruct proto-language constructions rather than morphs. Such constructions consist of the verb root combined with grammatical markers. The latter will include both verbal meanings (aspect / tense, modality, polarity) as well as the meanings referring to the subject of the clause, namely, the meanings of person and number, expressed by the so called predicative person markers (PPM), introduced in detail in the works by Vydrin [Выдрин 2010] and Zheltov [Желтов 2012].

In such verbal constructions, the structure is usually fixed and stable. There are three possible positions for verbal markers: initial (placed at the very beginning of the clause), postsubjective (placed between the predicative subject marker and the verb), and post-predicative (following the verb). For details of their syntax, one of the author's previous papers on the topic (Babaev 2011) may be consulted.

The post-subjective markers, locked in their position between the PPM and the verb, as a rule, become gradually fused with the former, generating a variety of pronominal sets or paradigms which in SW Mande are the only grammatical markers of both the subject and the predicate of the clause. Thus, the Zialo sentence gغ̀y $v a$ 'I will not come' incorporates both the person and the number of the subject and the TAMP meanings of the verb within the pronominal marker.

Therefore, the most obvious thing to reconstruct in the verbal sub-system of the morphosyntax would be a system of pronominal sets; the listing below generally follows Babaev 2010, with but a few slight modifications: Table 1 .

Analysis of these fused forms can give only a few ideas about how their elements, previously syntactically independent from each other, may have looked like. The following predicative markers can be identified:

- *à (imperfective), originally possibly *Nà

- *yá (focus / topic)

- *yé (comitative / instrumental)

- *'́x (negative), originally possibly ${ }^{*} N \varepsilon^{\prime} \dot{\varepsilon}$

Since we may be relatively sure that the origins of most of these morhemes lie within the verbal sphere, it would be interesting to suggest some verbal roots which could have been the source of the markers on this list.

Typologically, five semantic groups of verbs are well known to serve as the source of grammatical auxiliaries, and these can be traced across the Mande languages as well as other language families of the world. The following chart shows some examples of those roots, which, in some Mande idioms, can today be employed both as predicates and auxiliaries within the same clause: Table 2.

Comparative data allow to conclude that the imperfective morpheme *Nà can be traced back to * $n a$ 'to come', reconstructed for Proto-Mande. However, the ultra-short structure of the majority of the markers leaves little space for reliable hypotheses.

The following chart demonstrates some of the post-subjective predicative markers in SW Mande which may be projected onto the protolanguage level. The constructions are marked with the abbreviation of the pronominal set (BAS, FOC, IMP). The "Representation" column lists those SW Mande languages where the construction is actually witnessed. The external correspondences are taken from across the Mande language family (see the list of abbreviations at the end of the paper): Table 3.

For the moment, this seems like an exhaustive list of verbal markers which can be reconstructed for Proto-SW Mande. The absolute majority of them should be traced back to an even 
Table 3.

\begin{tabular}{|c|c|c|c|}
\hline Meaning & Construction & Representation & Correspondences \\
\hline $\begin{array}{l}\text { Resultative / } \\
\text { perfective }\end{array}$ & BAS V *á / ${ }^{*} N a ́$ & M Lk Z L K & $\begin{array}{l}\text { South Mande *-la, Beng -nã, Vai - } a \text { / - da, Manden -ta / -la } \\
\text { / -ra, Lele - } t a /-l a /-r a\end{array}$ \\
\hline Preterite & BAS V *í / ${ }^{*} \mathrm{Ni}^{\prime}$ & M Lk B Z L & Soso $-x i$ \\
\hline Aorist & BAS V $*-\jmath / * N \jmath$ & Lk B Z & \\
\hline \multirow[b]{2}{*}{ Imperfective } & $\mathrm{S}^{*} a /{ }^{*} \mathrm{\gamma} a$ & M Lk B Z L K & Manden *na, Vai na, Bisa ná, Bobo nà \\
\hline & S V-ma & M Lk B Z & $\begin{array}{l}\text { Mande * } m a \text { 'on the surface', Soso-Jalonke *-ma, Guro - } m \tilde{a} \text {, } \\
\text { Yaure - } m a /-a\end{array}$ \\
\hline \multirow{2}{*}{ Progressive } & $\mathrm{FOC}{ }^{*}$ to $\mathrm{V}\left({ }^{*} m a\right)$ & M Lk B Z & *to 'stand' \\
\hline & ${ }^{*} n a(N) \mathrm{S} \mathrm{V}$ & B Z L & *na 'time, when' \\
\hline Imperative & IMP V & M Lk B Z L K & = Mande \\
\hline Conditional & $S * \mathrm{~V}$ & Lk B L & \\
\hline \multirow{2}{*}{ Negative } & $\mathrm{S} * t a \mathrm{~V}$ & Z L K & Mande *ta 'go, leave' \\
\hline & $S^{*} \varepsilon(\varepsilon)<l \varepsilon ?$ & M B Z L & Vai -le, Manden ${ }^{*} t \varepsilon$, Lele té, Jeri $t \varepsilon$, Bozo te, Guro tē \\
\hline
\end{tabular}

higher chronological node, some to Proto-Mande or even further (cf. Proto-Niger-Congo *te / ${ }^{*} t e ́$ 'not be' as the negation marker).

The following conclusions may be offered:

- several morphs can be reconstructed for TA and negation marking in Proto-SW Mande;

- the origins of these morphs may in most cases be found in either the noun or the verb system;

- the basic opposition PFV / IPFV in the verb system is duly confirmed, the perfective cluster being marked by the basic (unmarked) pronominal set;

- modality is represented mostly by the imperative and conditional moods (probably irrealis);

- regeneration of the verbal systems and rapid 'cycles of grammaticalisation' make it a tricky task to go deeper than 1500-2000 years in reconstructing the Proto-Mande verb system.

\section{Literature}

Babaev 2010 - BABAEV, K. Person marking in South-West Mande languages: a tentative reconstruction. Mandenkan, 46, 2010, pp. 3-48.

Babaev 2011 - BABAEV, K. On the reconstruction of some tense/aspect markers in Proto-Mande. Journal of Language Relationship, 6, 2011. Pp. 1-23.

Dwyer 1973 - DWYER, David J. The comparative tonology of Southwestern Mande nominals. Michigan State University, Ph.D.

Бабаев 2011 - БАБАЕв К. В. Личное маркирование в юго-западных языках манде: опыт сравнения и реконструкции. Труды Института хингвистических исследований. Том 7, ч. 2. СПб.: Наука, 2011. Стр. $393-449$. [BABAEV K. V. Lichnoe markirovanie v yugo-zapadnykh yazykakh mande: opyt sravneniya i rekonstruktsii. Trudy Instituta lingvisticheskikh issledovanij. Tom 7, ch. 2. SPb.: Nauka, 2011. Str. 393-449.]

Выдрин 2006 - ВыдРИн В.Ф. К реконструкции фонологического типа и именной морфологии пра-манде // Труды Института лингвистических исследований. Т. II, ч. 2. СПб., 2006 [VyDRIN, Valentin. On the Recon- 
struction of the Phonological Type and Nominal Morphology of Proto-Mande. Works of the Institute of Linguistic Research, vol. 2, no. 2. Pp. 9-252. St. Petersburg: Nauka.], pp. 9-252.

Выдрин 2010 - Выдрин В. Ф. Ещё раз о “субъектных местоимениях" в южных языках манде: местоимения или предикативные показатели? // ВиногрАдОв В. А. (ред.). Основы африканского языкознания: синтаксис именных и глагольных групп. М..: Академия. Стр. 385-400. [VYDRIN V. F. Esche raz o "sub'ektnykh mestoimeniyakh" v yuzhnykh yazykakh mande: mestoimeniya ili predikativnye pokazateli? // VINOGRADOV V. A. (red.). Osnovy afrikanskogo yazykoznaniya: sintaksis imennykh i glagol'nykh grupp. M..: Akademiya. Str. 385-400.]

Желтов 2012 - ЖЕлтов А. Ю. Еще раз о местоименно-предикативных показателях в языках манде: к типологии маркеров персональности // Африканский сборник 2011. СПб.: МАЭ РАН, 2012, с. 197-203. [Zheltov A. Yu. Esche raz o mestoimenno-predikativnykh pokazatelyakh $\mathrm{v}$ yazykakh mande: $\mathrm{k}$ tipologii markerov personal'nosti // Afrikanskij sbornik 2011. SPb.: MAE RAN, 2012, s. 197-203.]

К. В. БАБАЕВ. К реконструкции глагольного морфосинтаксиса в праюгозападном манде.

Статья написана по материалам доклада о предварительных результатах коллективного исследовательского проекта «Нигеро-конголезский праязык: сравнение и реконструкция». В ней проанализированы сравнительные данные глагольного морфосинтаксиса юго-западных языков манде и определены возможности реконструкции праязыковых глагольных показателей.

Ключевые слова: языки манде, реконструкция, глагол, морфология, синтаксис, языки Африки. 
